\title{
Feeding ecology of Central Baltic sprat Sprattus sprattus larvae in relation to zooplankton dynamics: implications for survival
}

\author{
Miriam Dickmann ${ }^{1}$, Christian Möllmannn ${ }^{2,3, *}$, Rüdiger Voss $^{4}$ \\ ${ }^{1}$ Baltic Sea Research Institute Warnemünde, Seestr. 15, 18119 Warnemünde, Germany \\ ${ }^{2}$ Danish Institute for Fisheries Research, Charlottenlund Castle, 2920 Charlottenlund, Denmark \\ ${ }^{3}$ Institute for Hydrobiology and Fisheries Science, University of Hamburg, Olbersweg 24, 22767 Hamburg, Germany \\ ${ }^{4}$ Leibniz-Institute of Marine Sciences at the University of Kiel (IFM-GEOMAR), Düsternbrooker Weg 20, 24105 Kiel, Germany
}

\begin{abstract}
We investigated the larval feeding ecology of sprat Sprattus sprattus L., an important commercial fish species in the Central Baltic Sea. We collected seasonally resolved larval abundance and gut content as well as zooplankton data, with the goal of identifying mechanisms leading to variability in larval survival. Our results show sprat larvae feed progressively on larger food items as they grow during the season depending on their size and the composition of the available prey. We found first-feeding larvae early in the spawning season to prey exclusively upon microplankton. Small larvae fed mainly upon nauplii of the copepods Acartia spp., Temora longicornis and Centropages hamatus (ca. $65 \%$ ), whereas larger larvae consumed up to $80 \%$ Acartia spp. copepodites and adults, as well as cladocerans. Trends in sprat larval diets were to a large degree explainable by selective feeding. Feeding success and gut fullness increased linearly with larval size. Trophic niche breadth increased linearly until larvae reached a predator size of $16 \mathrm{~mm}$, after which it decreased. We explain the latter decline by a restricted size spectrum of prey available to larger sprat larvae, which points towards the importance of considering the structure of the zooplankton community when evaluating the predator size to niche breadth relationship. Our results suggest first-feeding Baltic sprat larvae to be always food-limited, while larger larvae are not. We hypothesize medium-sized sprat larvae to be the life stage that has the potential to cause most of the interannual variability in sprat larval survival, which is dependent on a match between larval production and the state of the plankton cycle.
\end{abstract}

KEY WORDS: Baltic Sea · Feeding ecology · Larval sprat · Selective feeding · Survival · Trophic niche breadth

- Resale or republication not permitted without written consent of the publisher

\section{INTRODUCTION}

Year-class strength of fish populations is generally assumed to be determined by early life history. Several hypotheses suggest a causal link between feeding, larval survival and subsequent recruitment, especially for the larval stage. The 'critical period hypothesis' links larval survival to food abundance during the transition from the yolk-sac stage to exogenous feeding (Hjort 1914). The 'match-mismatch hypothesis' relaxes the emphasis on a special period during larval life and points to the general importance of temporal overlap between the production of larvae and suitable prey (Cushing 1990). The basic idea is that the temporal coupling or decoupling of the production maxima of fish larvae and their prey organisms is the major source of recruitment variability. However, for species showing a prolonged spawning period, the majority of survivors reaching recruitment may not necessarily stem from the peak spawning time. Over the spawning period new larval cohorts emerge and develop into a continuously changing potential prey field. 
Body size of both prey and predator is linked directly to foraging success, and the relationship between prey size and predator size is of paramount importance for the outcome of species interactions (Scharf et al. 2000). In larval fish the prey niche breadth has been calculated to remain generally constant (e.g. Pearre 1986, Munk 1997) or to increase (Pepin \& Penney 1997) with increasing larval size. Knowledge on seasonal trends in general feeding ecology, i.e. feeding success and gut fullness, diet composition and selectivity, in relation to the food supply is a prerequisite for understanding the processes affecting the subsequent year-class strength of adult fish (Arrhenius 1996).

The small pelagic fish species sprat Sprattus sprattus L. is presently the dominant commercial fish stock in the Central Baltic Sea (Köster et al. 2003a). The recruitment level of sprat has generally increased since the mid-1980s (Parmanne et al. 1994), but its management is challenged by highly variable recruitment success and, hence, large fluctuations in stock size. Correlation studies of the spawning stock biomass and production of different egg stages, as well as larval and 0-group abundance, have demonstrated that the larval and early juvenile stages are critical for the survival of a sprat year class (Köster et al. 2003b). Information about the impact of larval feeding behaviour influencing the recruitment levels in sprat larvae in the Baltic Sea is scarce. Process-oriented investigations are difficult due to the protracted spawning period from March to August (Parmanne et al. 1994) and the need to acquire data both on larval abundance and suitable prey abundance during this period. Survivors might emerge from temporally distinct 'windows of survival' that may result from the availability of suitable prey, not only for the first-feeding larvae but also for all larval stages.

Historical gut content analyses revealed Baltic sprat larvae to have a very restricted prey spectrum and to be very sensitive to food limitation (Graumann et al. 1989). However, Voss et al. (2003) concluded that due to a larger niche breadth of sprat larvae, compared with Atlantic cod Gadus morhua, sprat larvae should be able to better cope with a changing prey field. Furthermore, they showed that sprat larvae generally exhibited a strong preference for developmental stages of Acartia spp. copepods (Voss et al. 2003), but no information on seasonal changes in the prey field, either with respect to size or to taxonomic composition, was given.

The aim of this study was to follow trends in feeding and prey selection of sprat larvae in relation to the seasonal population dynamics of their zooplanktonic prey. Our investigation was conducted in the Born- holm Basin, one of the major sprat spawning grounds in the Baltic Sea (Parmanne et al. 1994). In this area, seasonally resolved larval abundance and gut content data as well as zooplankton data were collected. We investigated trends in diet composition, selective feeding, gut fullness, feeding success and trophic niche breadth with the goal of identifying critical periods of larval survival.

\section{MATERIALS AND METHODS}

Sampling. We sampled sprat larvae during 13 cruises between March and November 2002 with the German research vessels RV 'Alkor', RV 'Heincke', RV 'Penk' and RV 'A. v. Humboldt' on a grid of 48 stations in the Bornholm Basin of the Central Baltic Sea (Fig. 1, Table 1). Larvae were collected with a $60 \mathrm{~cm}$ diameter Bongo sampler using nets with 335 and $500 \mu \mathrm{m}$ mesh sizes in double oblique hauls from the surface to $5 \mathrm{~m}$ above the sea floor. Abundance and larval length were measured for larvae collected on all cruises. Larval abundance during the season $\left(\mathrm{n} \mathrm{m}^{-2}\right)$ was calculated using information on filtered water volume and depth. Because of their better condition compared with those from the larger mesh, all larvae from $335 \mu \mathrm{m}$ mesh nets were used for gut content analyses, but were substituted with larvae from $500 \mu \mathrm{m}$ mesh if sufficient num-

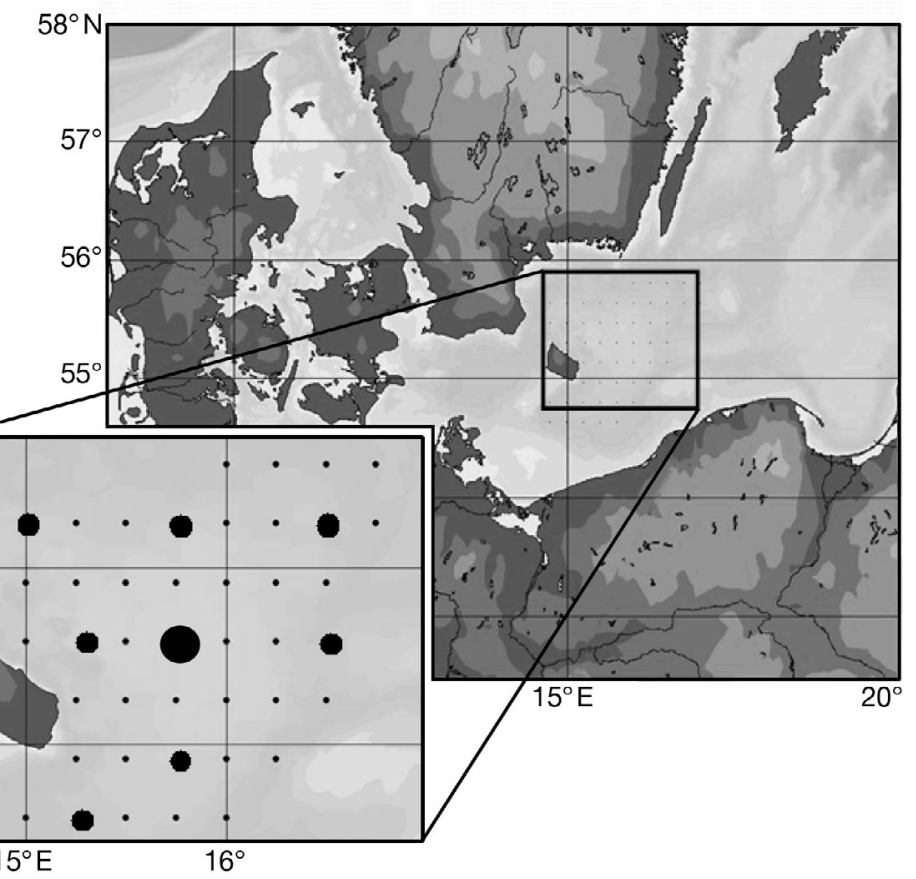

Fig. 1. Baltic Sea with inset showing the study site, the Bornholm Basin. Small dots are larval sampling grid, medium dots are stations with additional zooplankton sampling, large dot is station with additional vertical distribution sampling of sprat larvae 
Table 1. Sampling information. Ns, Number of larval sample stations; Ne, Number of larvae analysed for gut contents

\begin{tabular}{|llcc|}
\hline Sampling date & Vessel & Ns & Ne \\
\hline 17-19 Mar 2002 & RV 'A. v. Humboldt' & 8 & 439 \\
03-06 Apr 2002 & RV 'Alkor' & 4 & 52 \\
17-19 Apr 2002 & RV 'Penk' & 21 & - \\
06-11 May 2002 & RV 'Heincke' & 45 & - \\
23-28 May 2002 & RV 'A. v. Humboldt' & 21 & 740 \\
18-22 Jun 2002 & RV 'Alkor' & 11 & 596 \\
02-05 Jul 2002 & RV 'Alkor' & 35 & - \\
23-28 Jul 2002 & RV 'Alkor' & 36 & 232 \\
13-18 Aug 2002 & RV 'Heincke' & 48 & - \\
23-27 Aug 2002 & RV 'Alkor' & 26 & - \\
04-08 Sep 2002 & RV 'Alkor' & 44 & - \\
2-10 Oct 2002 & RV 'A. v. Humboldt' & 5 & - \\
12-16 Nov 2002 & RV 'Heincke' & 6 & - \\
\hline
\end{tabular}

bers were not available from the smaller mesh size. Gut contents were investigated for larvae collected on 5 cruises (Table 1). As feeding of sprat larvae occurs only during daylight (Voss et al. 2003), only larvae from daylight samples were used.

To determine the vertical feeding range of sprat larvae we recorded the vertical distribution of sprat larvae in May 2002 at a permanent station (Fig. 1) using a towed Multinet (mouth opening of $0.5 \mathrm{~m}^{2}, 335 \mu \mathrm{m}$ mesh size) deployed in $5 \mathrm{~m}$ steps from the surface to $80 \mathrm{~m}$ deep. Vertical distributions $\left(\mathrm{n} \mathrm{m}^{-3}\right)$ were calculated from 3 vertical profiles using information on filtered volumes.

We recorded the zooplankton prey field simultaneously with the sampling of sprat larvae at 9 stations of the grid (Fig. 1). Vertical zooplankton hauls were performed with a Multinet (mouth opening of $0.25 \mathrm{~m}^{2}$, $50 \mu \mathrm{m}$ mesh size) deployed in $10 \mathrm{~m}$ steps to a maximum depth of $80 \mathrm{~m}$. Using information on filtered water volumes, abundances $\left(\mathrm{n} \mathrm{m}^{-3}\right)$ of zooplankton species were calculated. All samples were preserved in a borax buffered $4 \%$ formaldehyde solution for laboratory analyses. We disregarded the daytime period when sampling the zooplankton prey field, as zooplankton in the area generally display limited diurnal vertical migration (Hansen et al. 2006).

Laboratory analyses. In the laboratory, the standard length (SL) of 2241 individual sprat larvae was measured to the nearest $10 \mu \mathrm{m}$. The whole alimentary channel of each individual larva was removed with a sharp needle, opened, and the gut contents analysed using a stereomicroscope. The analyses were conducted by first counting the intact individuals and afterwards checking for remains of individuals in an advanced state of digestion (e.g. mandibles). Where possible, all prey particles were identified to species. Five copepod stages were resolved including nauplii $(\mathrm{N})$, early copepodites $(\mathrm{C} 1-3)$, late copepodites (C4-5) and adults (C6). All, diatoms, ciliates and other unidentifiable small cells and microplankton remains were grouped together as 'microplankton'. The 'other plankton' group contained mainly copepod eggs and bivalve larvae as well as synchaetes and polychaetes. Zooplankton samples were also analysed using a stereomicroscope and the same sorting protocol was applied as for larval gut contents. We measured length and width of prey items in larval guts and from plankton samples to the nearest $10 \mu \mathrm{m}$. Dry weight of all copepod stages and cladocerans was calculated by applying estimates of Hernroth (1985) and Mauchline (1998) whereas that of synchaetes was calculated from estimates of Hernroth (1985) and Mullin (1969). Dry weight of copepod eggs was taken from Kiørboe \& Sabatini (1994) and those of bivalve larvae and polychaete larvae were taken from R. Nickolaus (unpubl. data). Dry weights of microplankton, diatoms and ciliates were calculated applying estimates from Pelegrí et al. (1999). No correction was applied due to changes in lengths caused by preservation.

Data analysis. We evaluated the gut fullness as the average number of prey items in larval guts weighted according to the larval length-frequency distribution. We tested for differences in gut fullness among months and predator size using the Kruskal-Wallis rank sum test. Furthermore, we calculated feeding success as the percentage of all analysed larvae containing food. Although feeding success includes the variability in the number of food items ingested, we considered our feeding/non-feeding index appropriate as we generally observed only very low numbers of prey items in the guts of larval sprat. We further performed simple regression analysis to evaluate the relationship between proportion of feeding larvae and larval length.

For the description of the diet composition of sprat larvae we computed the percent frequency of occurrence of each food item in all guts (excluding empty guts) as:

$$
F=100 n_{i} N^{-1}
$$

and the percentage of dry weight of each food item as:

$$
W=100 S_{i} S_{t}^{-1}
$$

where $n_{i}$ is the number of larvae with prey type $i$ in their guts, $N$ is the total number of analysed guts, $S_{i}$ is the mass of prey type $i$ and $S_{t}$ is the total mass of gut contents. For the determination of feeding trends we used both indices in 'Costello graphics' (Costello 1990). We used abbreviations for the prey types in the 'Costello graphics' (Table 2). For the statistical analysis of diet composition we used simple $\mathrm{R} \times \mathrm{C}$ contingency 
Table 2. Prey types

\begin{tabular}{ll|}
\hline Prey type & Abbreviation \\
\hline Acartia spp. nauplii & ACN \\
Acartia spp. C1-3 & AC13 \\
Acartia spp. C4-5 & AC45 \\
Acartia spp. C6 & AC6 \\
Temora longicornis nauplii & TEN \\
T. longicornis C1-3 & TE13 \\
T. longicornis C4-5 & TE45 \\
T. longicornis C6 & TE6 \\
Centropages hamatus nauplii & CEN \\
C. hamatus C1-3 & CE13 \\
C. hamatus C4-5 & CE45 \\
C. hamatus C6 & CE6 \\
Pseudocalanus acuspes nauplii & PSN \\
P. acuspes C1-3 & PS13 \\
P. acuspes C4-5 & PS45 \\
P. acuspes C6 & PS6 \\
Unidentified copepod stages & CS \\
Cladocerans & CLA \\
'Other plankton' & OP \\
Microplankton & MP \\
\hline
\end{tabular}

table analysis to test for independence between food categories and predator characteristics (Legendre \& Legendre 1998). This technique is able to identify the source of variation when diets are expressed as occurrences (Cortés 1997). Thus, a high number of cells with expected frequencies $<5$ should be avoided (Sokal \& Rohlf 1995).

For the analysis of taxonomic prey selectivity, we compared the mean prey abundance of all zooplankton sampling stations in the depth where sprat larvae occurred $(0$ to $20 \mathrm{~m}$ ) with the prey abundance in the larval guts. Selectivity values were calculated only for the main prey items, i.e. developmental stages of the copepods Acartia spp., Temora longicornis, Centropages hamatus and Pseudocalanus acuspes, as well as for cladocerans. We used the same abbreviations for the prey types as we used for the 'Costello graphics' (Table 2). To compare similar size ranges and to obtain sufficient numbers of larvae with sufficient food items to calculate selectivity indices, the larvae were grouped into 5 size classes $(<5.0,5.0-<10.0$, $10.0-<15.0,15.0-<20.0,20.0-<25.0 \mathrm{~mm})$. The index C (Pearre 1982) was used to describe the feeding selectivity; $\mathrm{C}$ varies from -1 to +1 where -1 indicates avoidance and +1 shows absolute preference for a certain prey type. Significance was calculated using the chisquare test.

To investigate size-related trends in feeding of sprat larvae, we studied the relationship between maximum, mean and minimum prey and larval logarithmic (log) lengths as well as trophic niche breadth. For the prey size to larval size relationship we esti- mated the mean of the log lengths of prey in each larval size class. Niche breadth was computed as the SD of the mean log prey size in each predator size class (Pearre 1986). We chose $0.5 \mathrm{~mm}$ larval size classes to get the maximum number of predator size classes containing 3 or more prey entries. We applied linear and nonlinear regression analyses to study the different relationships.

\section{RESULTS}

\section{Seasonal development of abundance and length of sprat larvae}

We found high abundances of sprat larvae between March and July and low abundances of larvae again in October and November (Fig. 2). Due to their seasonal occurrence, we investigated the feeding ecology of Baltic sprat larvae only for months where considerable abundance of larvae was available, i.e. March to July. Abundance increased towards a peak in early May after an intermediate minimum in late April. From late May onwards, the abundance of sprat larvae decreased, and they disappeared from the pelagic community in August. Mean and maximum larval length increased continuously from March to July, while the minimum lengths remained constant (Fig. 2).
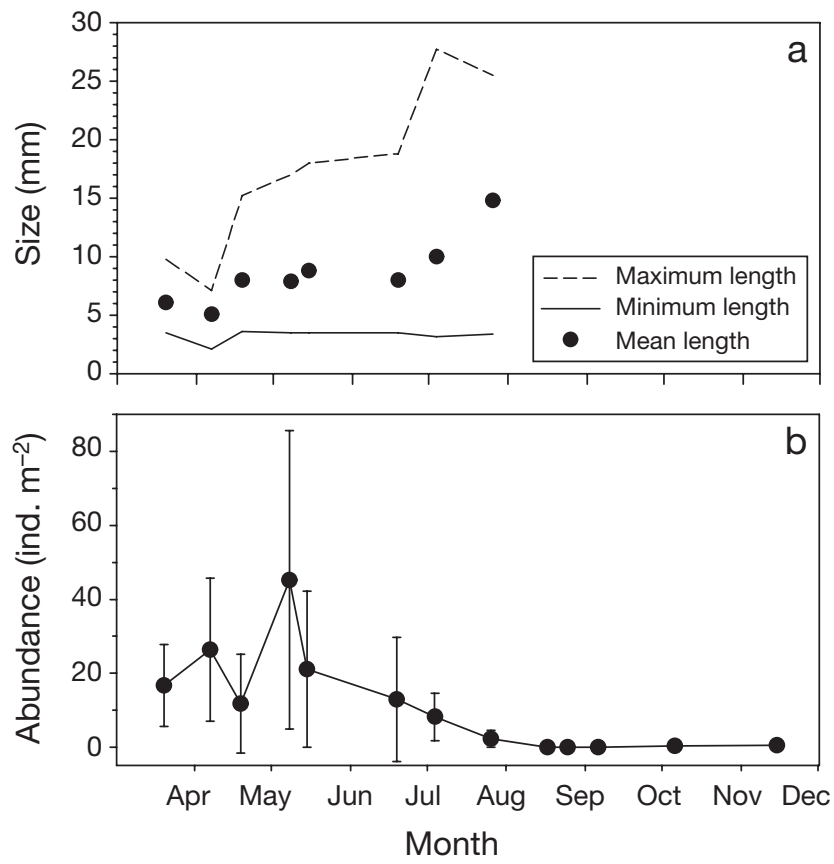

Fig. 2. Sprattus sprattus. Seasonal development of (a) larval length and (b) mean larval abundance (error bars represent $\pm \mathrm{SD})$ 


\section{Vertical distribution of sprat larvae}

We investigated the vertical distribution of sprat larvae during their peak abundance in May 2002 (Fig. 3). The observed vertical distribution reflects the typical ontogenetic vertical migration behaviour of Baltic sprat larvae. Baltic sprat eggs are neutrally buoyant in high salinity deep waters (ca. 14 to 15 psu compared with ca. $7 \mathrm{psu}$ in the surface layer) where the larvae also hatch. Consequently, at $55 \mathrm{~m}$ depth we observed a peak of recently hatched small individuals, which are nonfeeding yolk-sac larvae (Voss 2002). After hatching larvae migrated into the food-rich surface waters and hence medium sized and large sprat larvae were found in the upper $20 \mathrm{~m}$. We observed the maximum abundance at the $10 \mathrm{~m}$ depth where a secondary peak of small larvae was also found.

\section{Prey availability}

In accordance with their vertical distribution, we defined the zooplankton community in the upper $20 \mathrm{~m}$ to represent the prey field for feeding sprat larvae. The prey availability consisted of the copepods Acartia spp., Temora longicornis, Centropages hamatus and Pseudocalanus acuspes as well as cladocerans (Fig. 4). Nauplii of all species dominated the prey field in April and May. Highest abundances were observed for $T$.

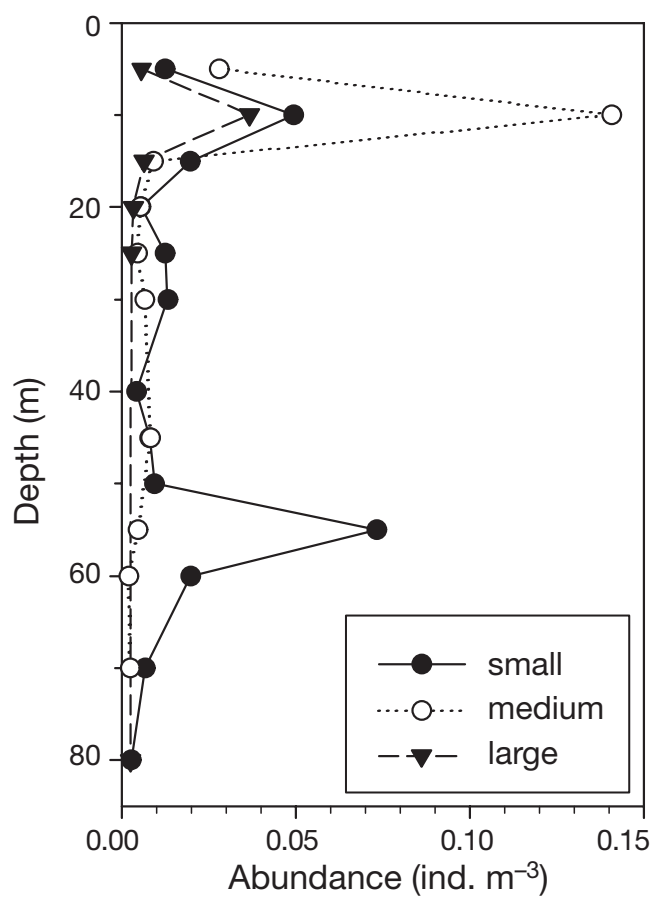

Fig. 3. Sprattus sprattus. Vertical distribution of larvae in May 2002 longicornis, which peaked in April, and Acartia spp., which peaked in May. In May maximum abundances of $\mathrm{C} 1-3$ and $\mathrm{C} 4-5$ copepodite stages were observed as well, with $T$. longicornis being the most abundant followed by Acartia spp. and C. hamatus. From June onward, adults (C6) of Acartia spp. and T. longicornis generally dominated the copepod community, while in July and August, cladocerans were by far the most abundant zooplankton group.

We characterized the prey field by computing the mean size of the prey items available to sprat larvae (Fig. 5). The mean size of the individual items in the plankton more than doubled from April to June and remained constant thereafter.

\section{Diet composition}

At the beginning of the sprat spawning season (in March and April), sprat larval guts contained microplankton almost exclusively (data not shown). In May, nauplii of Temora longicornis, Centropages hamatus and Acartia spp. dominated the diet (Fig. 6). The group 'other plankton' and early copepodites of Acartia spp. were also important in May. In June unidentified nauplii as well as nauplii of T. longicornis and Acartia spp. were the most frequently occurring prey items, while adults of Acartia spp. dominated the diet in weight. From July onward C4 to 5 and C6 stages of Acartia spp., adult C6 C. hamatus and cladocerans were the dominant prey items.

The seasonal progression of the sprat larval diet from smaller to larger prey items was also apparent when the diet composition among different size classes was compared (Fig. 7). We found the smallest feeding larvae $(<5.0 \mathrm{~mm})$ to feed mainly on microplankton and Temora longicornis nauplii. For 5.0 to $<10.0$ mm larvae, copepod nauplii (mainly of T. longicornis and Acartia spp.) dominated the gut contents, while the gut contents of 10.0 to $<15.0 \mathrm{~mm}$ larvae contained mostly C6 Acartia spp. and cladocerans. In general, the largest sprat larvae $(15.0$ to $<25.0 \mathrm{~mm}$ ) preyed upon $\mathrm{C} 6$ of Acartia spp. and Centropages hamatus, cladocerans and C4 to 5 of Acartia spp.

We used a contingency table analysis to statistically evaluate differences in diet among months and size classes of larval sprat. We excluded March and April from the analysis of temporal differences because during these months mainly microplankton and 'other plankton' occurred in the guts; including them would have lead to a large number of cells with expected frequencies $<5$ for the other food items, which should be avoided (Sokal \& Rohlf 1995). For the same reason of avoiding cells with low numbers or values of 0 , we pooled all copepodite stages and adults $(\mathrm{C} 1-6)$ in one group per species. 


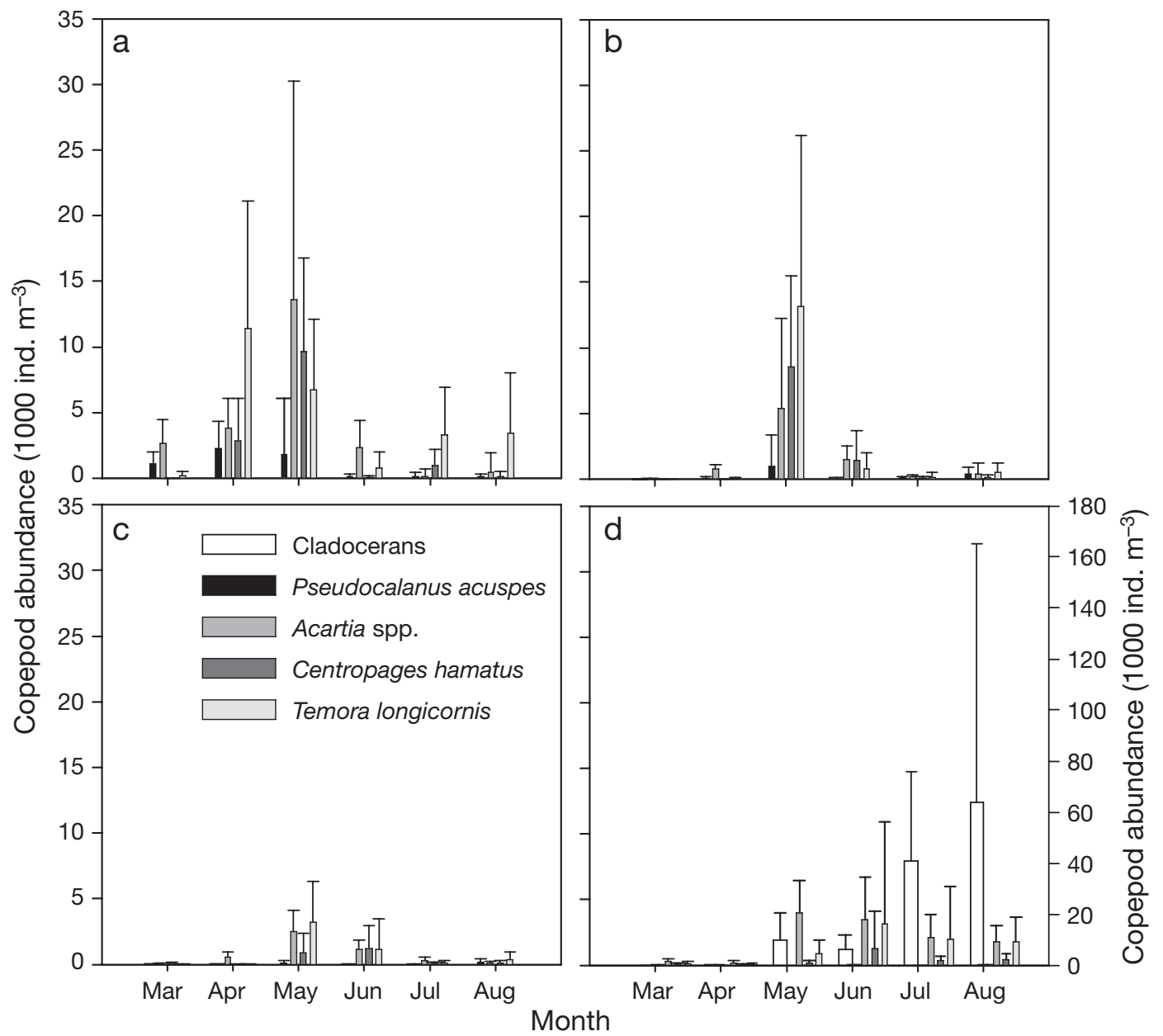

Fig. 4. Seasonal development of the mean larval sprat prey availability: (a) nauplii, (b) copepodite stages C1 to 3, (c) copepodite stages $\mathrm{C} 4$ to 5, (d) adult copepods and cladocerans (error bars represent \pm SD)

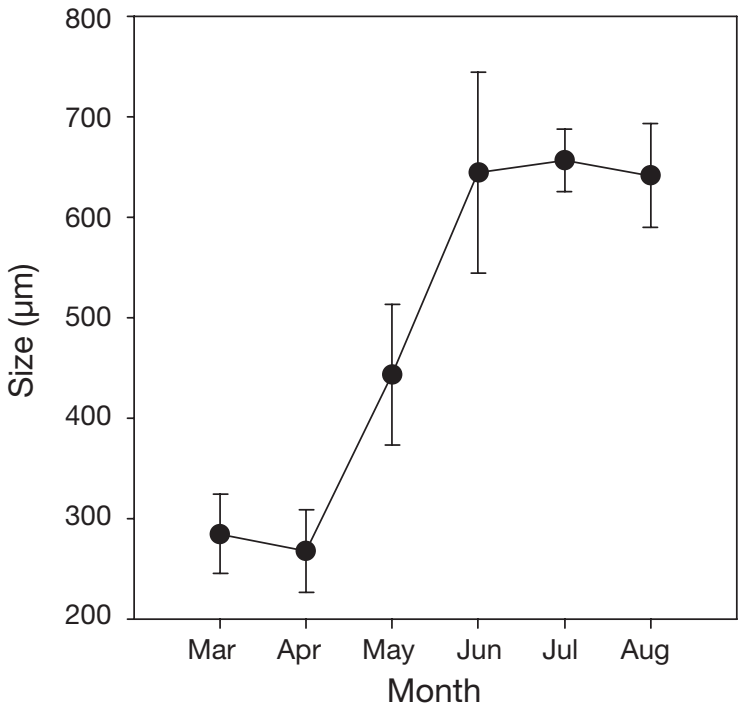

Fig. 5. Seasonal development of the mean individual length of plankton in 0 to $20 \mathrm{~m}$ depth (error bars represent $\pm \mathrm{SD}$ )
Comparing the diet in May, June and July we derived a grand total $\chi^{2}$ value that indicated a highly significant difference $\left(\chi^{2}=452.48, \mathrm{df}=18, \mathrm{p}<0.0001\right)$ in the occurrence of prey types. Among prey types, the main source of variation was in Acartia spp. $\left(\chi^{2}=\right.$ 144.34) and among months July showed the greatest variation $\left(\chi^{2}=229.68\right)$. The contingency table analysis of the difference between size classes also showed a significant grand total $\chi^{2}$ value $\left(\chi^{2}=451.95, \mathrm{df}=27, \mathrm{p}<\right.$ $0.0001)$. Most of the variation in prey types again came from Acartia spp. $\left(\chi^{2}=144.17\right)$, whereas for size classes the highest variability was observed for 5.0 to $<10.0 \mathrm{~mm}$ long larvae $\left(\chi^{2}=137.26\right)$.

\section{Selective feeding}

We calculated selectivity indices for different larval size classes and prey items for May, June and July when sufficient numbers of filled guts for a wide 

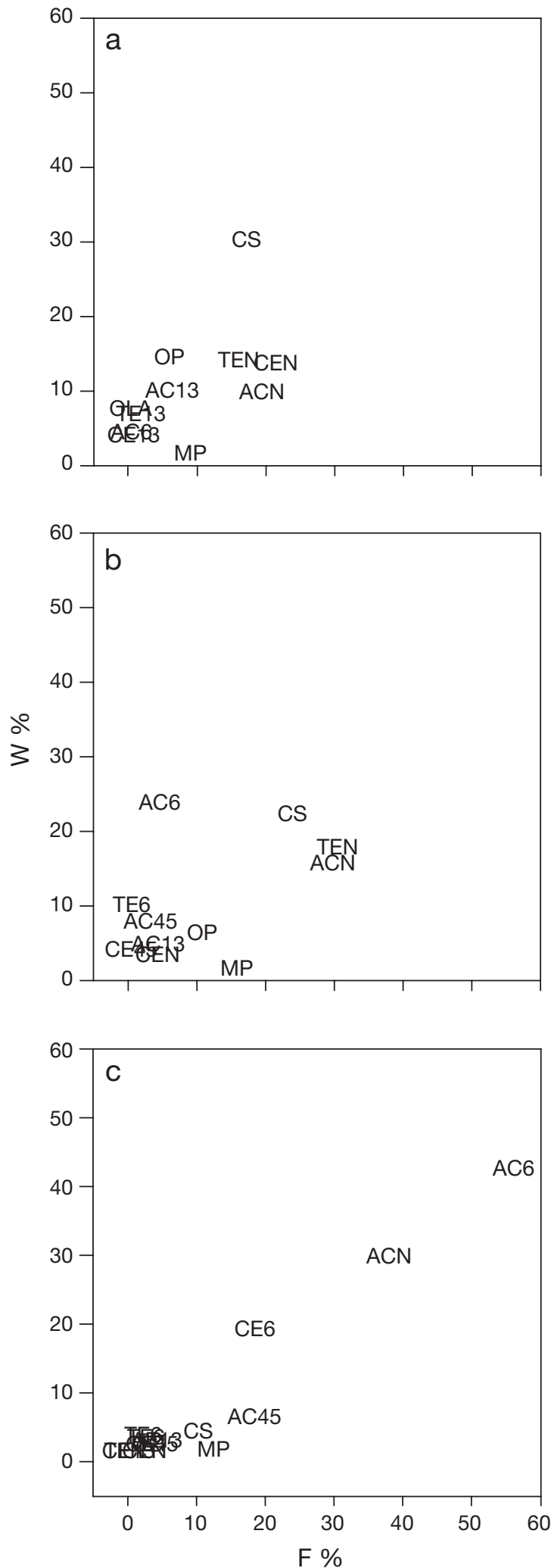

Fig. 6. Sprattus sprattus. Diet composition of larvae in (a) May, (b) June and (c) July (W \% is percentage of dry weight of each food item in the gut, F \% is frequency of occurrence of each food item in the gut; for abbreviations see Table 2) range of larval sizes were available (Fig. 8). We found significant differences in selective feeding between larval size classes and months. In all months, the smallest larvae $(\leq 10.0 \mathrm{~mm})$ selected nauplii of Acartia spp., Centropages hamatus and Temora longicornis. With increasing size (10.0 to $<20.0 \mathrm{~mm}$ ), larvae selected developmental stages of Acartia spp. in May and June, and additionally adult C. hamatus in July. The largest larvae (20.0 to $<25.0 \mathrm{~mm}$ ), observed only in July, also selected Acartia spp. life stages as well as C6 stage of C. hamatus. In all months, a negative selection was calculated for developmental stages of Pseudocalanus acuspes, $T$. longicornis and cladocerans.

\section{Gut fullness and feeding success}

Gut fullness in terms of numbers increased until July with a smaller intermediate peak in April (Fig. 9). Gut fullness in terms of weight increased constantly from low levels throughout a large part of the season to a very pronounced peak in July. We observed both indices of gut fullness to increase with larval length, displaying a pronounced increase in the largest length group (Fig. 9). A Kruskal-Wallis rank sum test showed significant differences in gut fullness between mo $\left(\chi^{2}=\right.$ 125.53, $\mathrm{p}<0.001$ for prey numbers and $\chi^{2}=129.39, \mathrm{p}<$ 0.001 for prey weight) and predator sizes $\left(\chi^{2}=217.01\right.$, $\mathrm{p}<0.001$ for prey numbers and $\chi^{2}=219.52, \mathrm{p}<0.01$ for prey weight).

We evaluated feeding success on a monthly basis. Almost no larvae were found feeding in March, indicating that feeding probably started in April (data not shown). From May onward the proportion of feeding larvae was significantly $(\mathrm{p}<0.01)$ related to larval length (Fig. 10). While the regression model explained a large part of the variability in the data in May, more variable relationships were found for June and July.

\section{Prey-predator size relationships and trophic niche breadth}

The mean log-length of ingested prey increased with sprat larval size up to a plateau at ca. $16 \mathrm{~mm}$ (Fig. 11a). A nonlinear regression analysis revealed a highly significant relationship $\left(\mathrm{r}^{2}=0.85, \mathrm{p}<0.01\right)$. Maximum prey length also increased to a plateau, in this case when larvae reached ca. $13 \mathrm{~mm}$ (Fig. 11b). Minimum logprey length remained constant to sprat larval length of ca. $12 \mathrm{~mm}$, but increased afterwards as larvae grew larger. Nonlinear regression analyses revealed a highly significant relationship with larval length for 

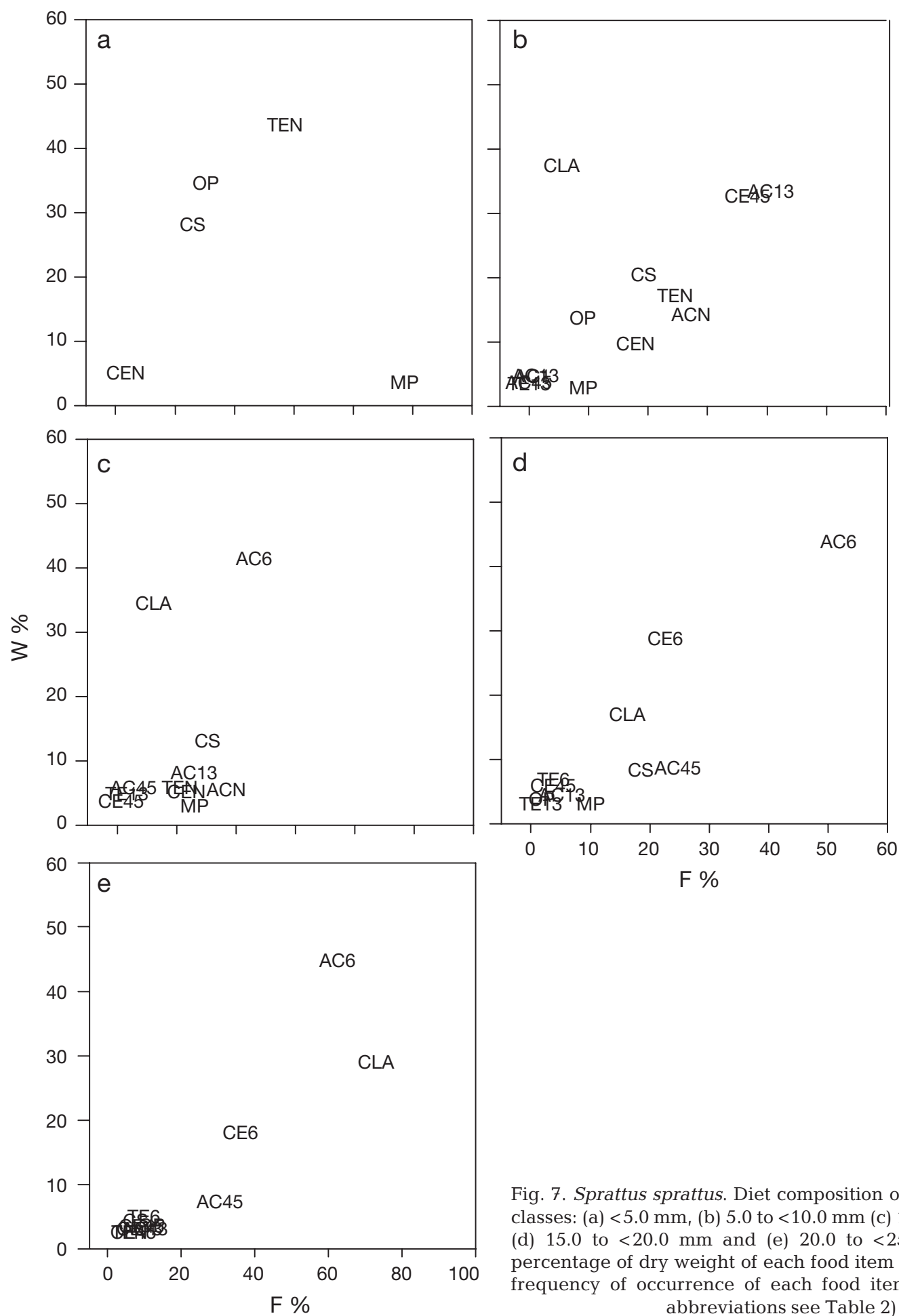

Fig. 7. Sprattus sprattus. Diet composition of different length classes: (a) $<5.0 \mathrm{~mm}$, (b) 5.0 to $<10.0 \mathrm{~mm}$ (c) 10.0 to $<15.0 \mathrm{~mm}$, (d) 15.0 to $<20.0 \mathrm{~mm}$ and (e) 20.0 to $<25.0 \mathrm{~mm}$ (W\% is percentage of dry weight of each food item in the gut, $\mathrm{F} \%$ is frequency of occurrence of each food item in the gut; for abbreviations see Table 2)

both maximum $\left(\mathrm{r}^{2}=0.94, \mathrm{p}<0.01\right)$ and minimum logprey length $\left(\mathrm{r}^{2}=0.58, \mathrm{p}<0.01\right)$.

Niche breadth also increased in linear fashion with increasing larval length to ca. $16 \mathrm{~mm},\left(\mathrm{r}^{2}=0.79, \mathrm{p}<\right.$ 0.01 ), but was unrelated to length for larger larvae

(Fig. 11c). Larger larvae on average showed a smaller niche breadth, but with a considerable variability. A sequence of linear regressions of niche breadth vs sprat larval length starting with the length interval 5.0 to $10.0 \mathrm{~mm}$ and subsequently 

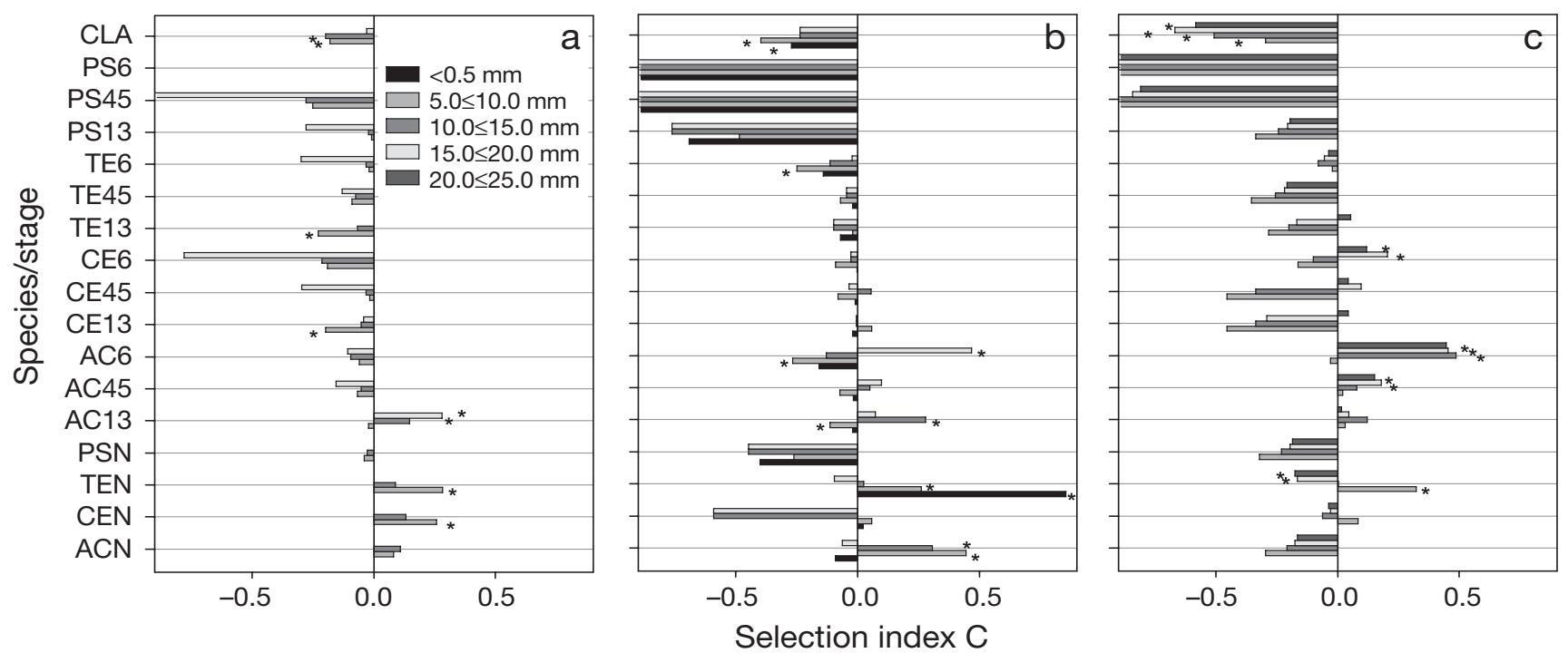

Fig. 8. Sprattus sprattus. Size-specific selectivity indices (Index C) for (a) May, (b) June and (c) July (* indicates significant selection at the $5 \%$ level)

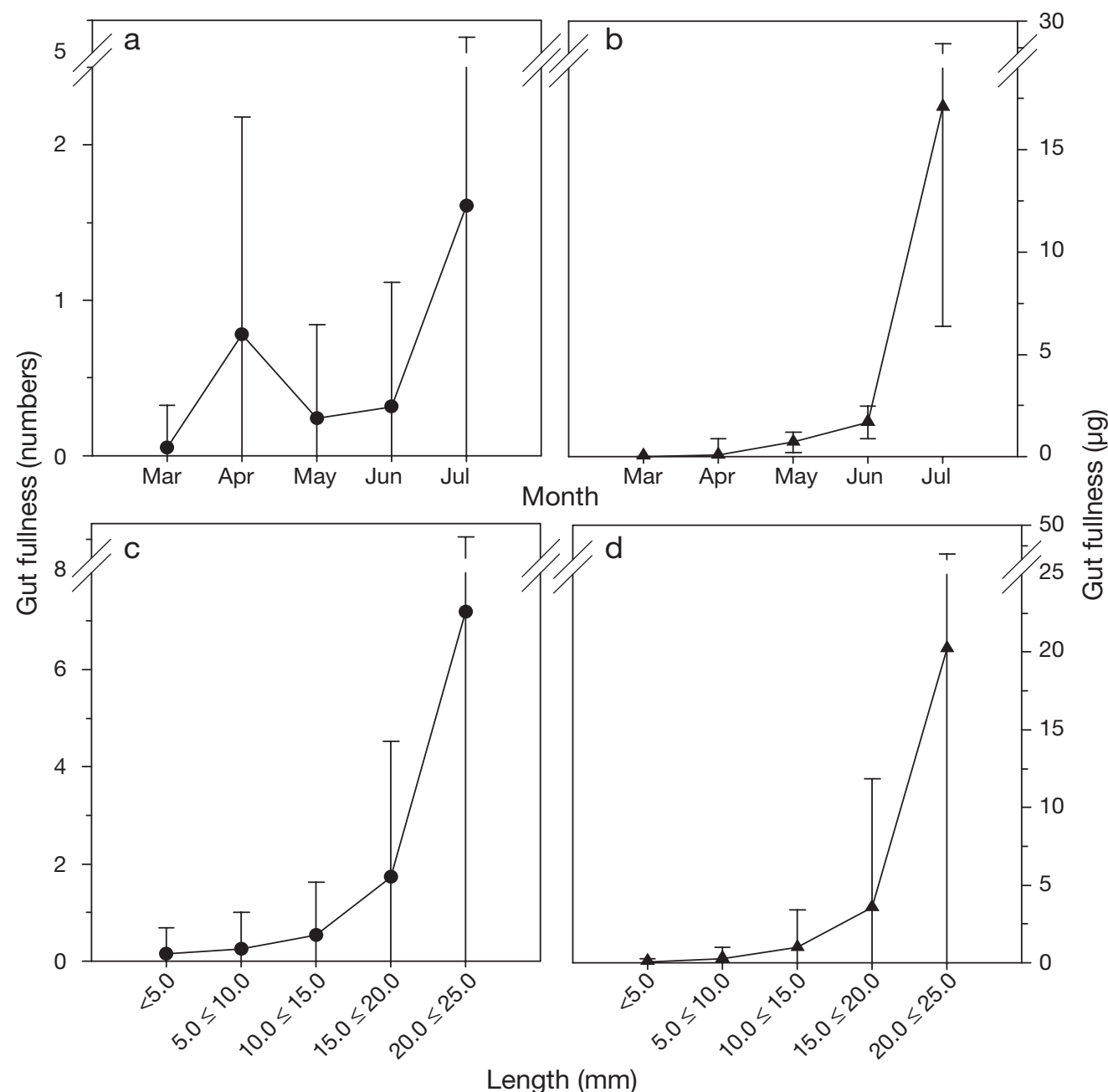

Fig. 9. Sprattus sprattus. $(a, b)$ Seasonal and $(c, d)$ size-dependent development of gut fullness. Gut fullness in terms of numbers (O) and weight $(\mathbf{\Delta})$. Error bars: SD 


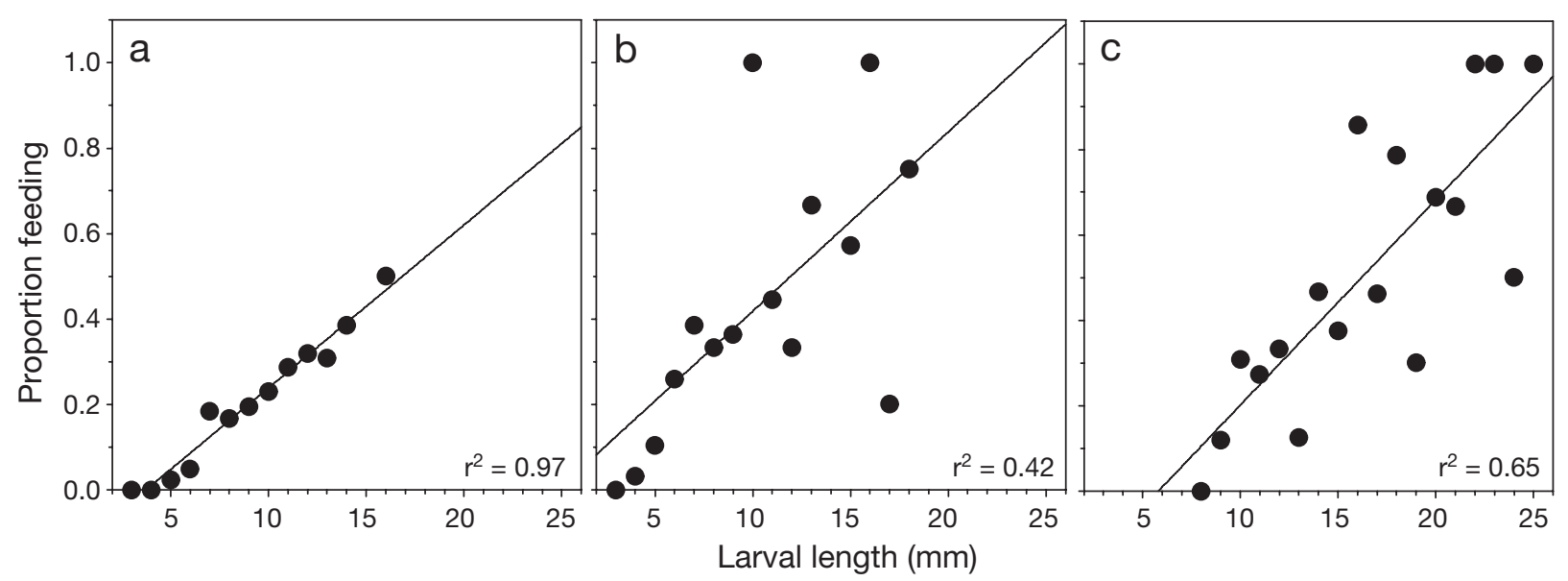

Fig. 10. Sprattus sprattus. Proportion of feeding larvae in relation to larval length for (a) May, (b) June and (c) July
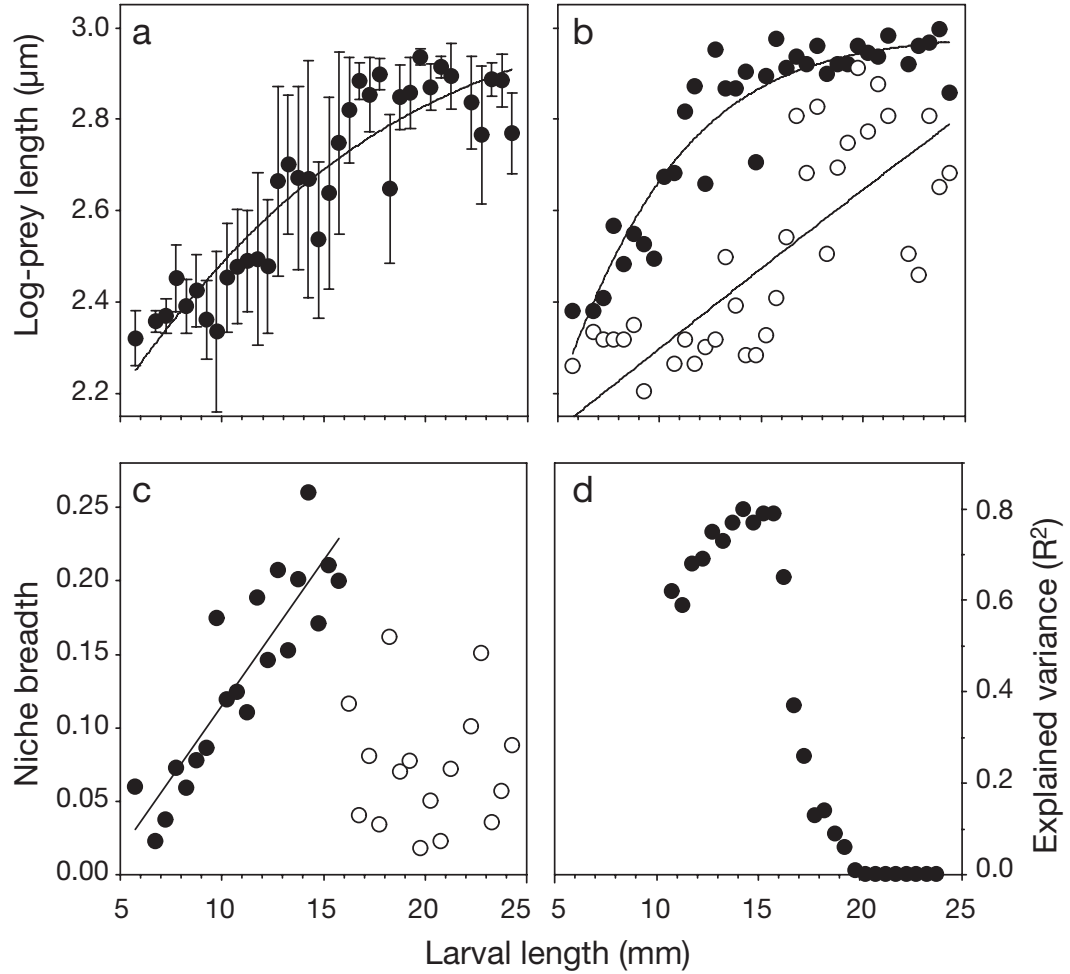

Fig. 11. Sprattus sprattus. Larval length in relation to (a) log mean prey length $( \pm \mathrm{SD})$, (b) $\log$ maximum and minimum prey length (- $\log$ maximum prey length, $\mathrm{O}$ : log minimum prey length, lines are non-linear regression for the log maximum prey length and linear regression for the log minimum prey length), (c) trophic niche breadth (line is linear regression for the niche breadth of 6.0 to $16.0 \mathrm{~mm}$ larval length), and (d) explained variance ( $\mathrm{R}^{2}$ ) for the regression of larval length vs niche breadth by subsequently adding length intervals

adding one data point (i.e. length class) per step, revealed the threshold point where the regression loses significance to be at a larval length of $>16.0 \mathrm{~mm}$ (Fig. 11d).

\section{DISCUSSION}

\section{Diet composition and selective feeding}

In agreement with earlier studies in the Baltic Sea (Graumann et al. 1989, Arrhenius 1996, Voss et al. 2003) and in other regions (e.g. Coombs et al. 1992) we found copepods and cladocerans to dominate the diet of sprat larvae. Contrary to an earlier study (Voss et al. 2003), we observed a considerable amount of microplankton in the guts of small firstfeeding larvae $(<10.0 \mathrm{~mm})$. A reason for this difference between our findings and that of Voss et al. (2003) may be that most of the microplankton are fragile and nonloricate species and can easily be decomposed without digestive residue in the larval guts, thus remaining undetected (Stoecker \& Govoni 1984, Fukami et al. 1999). Several other studies suggest that fish larvae start feeding on diatoms and/or 'protozoan-like cells', including flagellates and ciliates (e.g. Fukami et al. 1999), which might serve as a trial food to establish the feeding behaviour of larval fish or a supplement to low nauplii concentrations (Stoecker \& Govoni 1984). We observed a peak of first-feeding larvae in $10 \mathrm{~m}$ depth, where dinoflagellates and other microzooplankton were abundant at the beginning of the sprat spawning season (J. van Beusekom pers. comm.). Thus, we conclude that microplankton can be an important food source for first-feeding Baltic sprat larvae, although the nutritional value of these items remains unknown. 
We found a positive selection and, thus, a dominance of Acartia spp. developmental stages in the diet of Baltic sprat larvae. This is counter-intuitive as Acartia spp. display greater burst speed at escape compared with other copepods such as Pseudocalanus acuspes and Oithona sp. (Checkley 1982) and show a high alertness to hydrodynamic signals (Viitasalo et al. 2001). However, Viitasalo et al. (2001) also observed that Acartia spp. performs only a weak escape jump with a small escape distance, which is positively related to attack success of a predator (e.g. Caparroy 2000). This might have contributed to the observed high selection of Acartia spp., which confirms earlier studies from the Baltic Sea (Arrhenius 1996, Voss et al. 2003).

Cladocerans were the main prey for the largest sprat larvae, although selection indices for this taxonomic group were negative. We explain this apparent contradiction by the extremely high population size of cladocerans during summer allowing sprat larvae to feed on cladocerans without restriction.

Selectivity estimates can generally be biased due to a spatio-temporal mismatch between the sampling of predators and prey. In our study zooplankton abundance and larval diets were not compared on a station by station basis. Rather, selection indices were calculated by integrating gut contents and food availability over all sampled stations from one survey. This integration over a large number of samples was necessary due to, in general, low numbers of feeding larvae and ingested prey items. Further, we assumed the vertical feeding range of the larvae to be restricted to the upper $20 \mathrm{~m}$ of the water column where most of the larvae were observed. Hence, our prey concentration is averaged over a broad scale relative to the larvae's feeding ambit (Pepin 2004). Some evidence exists that copepods are aggregated in fine-scale layers (e.g. Gallager et al. 2004) associated with hydrographical discontinuities, where high prey abundances are found as well (e.g. Munk et al. 1999). Our sampling did not allow resolving the fine-scale distribution of the prey, but we believe that such distribution patterns might have a strong influence on observed selection indices.

\section{Predator and prey size related feeding trends}

Earlier studies observed positive relationships between body size and number of prey items ingested (e.g. Cass-Calay 2003, Reiss et al. 2005). In this study we observed only a slight increase in the number of prey items in the guts of the smaller size classes ( $<15.0 \mathrm{~mm}$ ) and a pronounced increase in prey numbers in guts of larger larvae (>15.0 mm). In combination with a very high share of non-feeding small larvae this indicates a critical period during this larval stage.
Furthermore, this finding supports the hypothesis that given natural prey densities, these small fish larvae can not afford to choose actively amongst several simultaneously available prey items (Browman 2005). Higher variation in the larval length to feeding proportion relationship, as observed for larger larvae in June and July, is at least partly due to lower sample sizes in these size classes. Our data unfortunately are not sufficient to judge if this indicates an additional biological phenomenon related to predator-prey interaction.

Feeding theory predicts that under food-limited conditions the niche breadth of larval fish should increase due to the ingestion of a wider range of prey sizes (e.g. Reiss et al. 2005). However, several studies found no significant relationship between niche breadth and larval size (e.g. Pearre 1986, Reiss et al. 2005). Pepin \& Penney (1997) observed an increase in niche breadth with larval growth for 6 out of 11 species investigated, while Scharf et al. (2000) observed a decrease in breadth of relative prey sizes for a number of the investigated fish species. For Baltic sprat we observed the niche breadth of sprat larvae to increase linearly until a length of ca. $16.0 \mathrm{~mm}$. Afterwards the relationship disappears and larger larvae had a lower and highly variable niche breadth. We explain this pattern by a combination of larval growth and the seasonal plankton cycle. In the beginning of the season sprat larvae are small and, thus, limited to small food items such as nauplii, which are available in the plankton. Consequently small larvae displayed a small niche breadth. As they grow during spring, larvae became able to cope with larger prey items that also developed in the plankton. However, in spring 2002, larvae fed on smaller prey items along with large ones, thus increasing their niche breadth. This may be a result of large prey being limited. Feeding experiments showed that larvae increase their niche breadth when density of major prey is low (Munk 1995).

In July most of the larvae were in the largest size classes when sufficient numbers of large prey items were also available in the plankton. Consequently these larvae again displayed a smaller niche breadth. Our results show that when evaluating the relationship between larval size and niche breadth, the taxonomic and size composition of the prey field has to be considered. This is especially true when investigating this relationship for species with a prolonged spawning time during which the zooplankton community changes. For example, Voss et al. (2003) found no correlation of niche breadth to larval length when the entire larval length range of 5 to $21 \mathrm{~mm}$ was used. However, when considering our findings, a comparable pattern of an increase in niche breadth from 6 to $13 \mathrm{~mm}$ larval size and a decrease afterwards appears (Fig. 6 in Voss et al. 2003). 


\section{Implications of observed feeding trends for sprat larval survival}

Based on our results on temporal- and size-dependent trends in Baltic sprat larval feeding ecology we were able to identify potential critical periods during larval development. Our results suggest that first-feeding sprat larvae $(<10.0 \mathrm{~mm})$ are generally food-limited because of a very low feeding success and a rapidly increasing niche breadth. This implies that even if sprat larvae are born during the spring nauplii production peak, they probably suffer high mortality. In contrast, we found the largest larvae $(>16.0 \mathrm{~mm})$, which occur mainly during summer, not to be food-limited, as evidenced by their high feeding success. In summer a sufficient standing stock of larger zooplankton is available to these larvae. Our results further indicate that medium-sized sprat larvae (10.0 to $16.0 \mathrm{~mm})$ are at the life-stage that has the potential to cause most of the interannual variability in survival. We base this hypothesis on the maximum trophic niche breadth we found for this part of the population, pointing towards the need to incorporate all available prey types in the diet. We further conclude that a temporally limited 'window of survival' exists for this larval stage that depends on the prey field they encounter. Larvae born too early in the season, despite being able to profit from high nauplii abundances for first-feeding larvae, suffer from the restricted size-spectrum of the zooplankton available when they grow. In contrast, larvae born too late in the season will suffer from low nauplii availability. During a transition period larvae encounter both enough nauplii for first-feeding and later copepodite stages for their further growth. Hence, we hypothesise that the match of larval production relative to the period where the broadest size-spectrum of zooplankton is available (e.g. in summer) determines larval survival. We find support in a parallel study by Baumann et al. (2006) who investigated spatio-temporal patterns in growth of Baltic Age-0 sprat from the same year (2002) and showed that surviving sprat larvae were in fact born during the summer.

Besides food availability other factors may also have been important for variable larval survival. A negative influence of temperature $<5^{\circ} \mathrm{C}$ on sprat egg and yolksac larval survival has been shown by Nissling (2004). In the early spawning season of 2002 (April, May), such low temperatures were recorded suggesting reduced survival is independent of food supply. Furthermore, low temperatures might negatively affect survival by slowing down growth and developmental rates, thereby prolonging the phase of potential predation. For larval Baltic sprat, predation is of minor importance (Köster \& Möllmann 2000). As the direct temperature effect and the effect of food availability both acted towards a better survival of summer- over spring-born larvae, it becomes difficult to separate the confounding effects. However, a parallel study by Voss et al. (2006) investigating seasonal variability in sprat larval condition and survival also showed that larvae $>12.0 \mathrm{~mm}$ displayed a higher survival when born in June compared with that in April and May. These differences could be attributed to the difference in the composition of the available prey and supports our results showing that the best food availability for larval survival is during summer.

In conclusion, survival of Baltic sprat larvae is favoured by higher temperature decreasing mortality either directly (Nissling 2004) or by increasing the biomass of Acartia spp. as Möllmann et al. (2003) observed during the 1990s. The combined effect may, thus, have resulted in high recruitment and consequently the strong increase in the stock size of Baltic sprat during this decade (Köster et al. 2003a).

Acknowledgements. The authors are grateful to R. Hinrichs for helping to identify zooplankton species and J. Schulz, J. Alheit, M. A. Peck as well as B. von Bodungen for critical reviews and helpful comments on earlier versions of the manuscript. This study was funded by the Federal Ministry of Education and Research (BMBF) within the German GLOBEC project. We thank the crews of the RV 'Alkor', RV 'A. v. Humboldt' and RV 'Heincke'.

\section{LITERATURE CITED}

Arrhenius F (1996) Diet composition and food selectivity of 0group herring (Clupea harengus L.) and sprat (Sprattus sprattus L.) in the northern Baltic Sea. ICES J Mar Sci 53: 701-712

Baumann H, Hinrichsen HH, Voss R, Stepputtis D, Grygiel W, Clausen LW, Temming A (2006) Linking growth to environmental histories in central Baltic young-of-the-year sprat, Sprattus sprattus: an approach based on otolith microstructure analysis and hydrodynamic modelling. Fish Oceanogr 15:465-476

Browman HI (2005) Applications of sensory biology in marine ecology and aquaculture. Mar Ecol Prog Ser 287:266-269

Caparroy P (2000) Modelling the attack success of planktonic predators: patterns and mechanisms of prey size selectivity. J Plankton Res 22:1871-1900

Cass-Calay S (2003) The feeding ecology of larval Pacific hake (Merluccius productus) in the California current region: an updated approach using a combined OPC/ MOCNESS to estimate prey biovolume. Fish Oceanogr 12: $34-48$

Checkley DM Jr (1982) Selective feeding by Atlantic herring (Clupea harengus) larvae on zooplankton in natural assemblages. Mar Ecol Prog Ser 9:245-253

Coombs SH, Nichols JH, Conway DVP, Milligan S, Halliday NC (1992) Food availability for sprat larvae in the Irish Sea. J Mar Biol Assoc UK 72:821-834

Cortés E (1997) A critical review of methods of studying fish feeding based on analysis of stomach contents: application to elasmobranch fishes. Can J Fish Aquat Sci 54: $726-738$ 
Costello MJ (1990) Predator feeding strategy and prey importance: a new graphical analysis. J Fish Biol 36:261-263

Cushing DH (1990) Plankton production and year class strength in fish populations: an update of the match/mismatch hypothesis. Adv Mar Biol 26:249-293

Fukami K, Watanabe A, Fujita S, Yamaoka K, Nishijima T (1999) Predation on naked protzoan microzooplankton by fish larvae. Mar Ecol Prog Ser 185:285-291

Gallager SM, Yamazaki H, Davis CS (2004) Contribution of fine-scale vertical structure and swimming behavior to formation of plankton layers on Georges Bank. Mar Ecol Prog Ser 267:27-43

Graumann GB, Lisiunenko LN, Sidrevics LL (1989) Some aspects of Baltic fish larvae feeding. Fischerei-Forschung 27:7-13

Hansen F, Möllmann C, Schütz U, Neumann T (2006) Spatiotemporal distribution and production of calanoid copepods in the Central Baltic Sea. J Plankton Res 28:39-54

Hernroth L (1985) Recommendations on methods for marine biological studies in the Baltic Sea mesozooplankton biomass assessment. The Baltic Marine Biologists, Publ No. 10

Hjort J (1914) Fluctuations in the great fisheries of Northern Europe viewed in the light of biological research. Rapp PV Réun Cons Perm Int Explor Mer 20:1-228

Kiørboe T, Sabatini M (1994) Reproductive and life cycle strategies in egg-carrying cyclopoid and free-spawning calanoid copepods. J Plankton Res 16:1353-1366

Köster FW, Möllmann C (2000) Egg cannibalism in Baltic sprat Sprattus sprattus. Mar Ecol Prog Ser 196:269-277

Köster FW, Möllmann C, Neuenfeldt S, Vinther M and 6 others (2003a) Fish stock development in the Central Baltic Sea (1976-2000) in relation to variability in the physical environment. ICES Mar Sci Symp 219:294-306

Köster FW, Hinrichsen HH, Schnack D, St John MA and 7 others (2003b) Recruitment of Baltic cod and sprat stocks: identification of critical life stages and incorporation of environmental variability into stock-recruitment relationships. Sci Mar 67:129-154

Legendre P, Legendre L (1998) Numerical ecology. Elsevier, New York

Mauchline J (1998) The biology of calanoid copepods. Adv Mar Biol 33:1-710

Möllmann C, Köster FW, Kornilovs G, Sidrevics L (2003). Interannual variability in population dynamics of calanoid copepods in the Central Baltic Sea. ICES Mar Sci Symp 219:294-306

Mullin MM (1969) Production of zooplankton in the ocean: the present status and problems (RV). Oceanogr Mar Biol $7: 293-314$

Munk P (1995) Foraging behaviour of larval cod (Gadus morhua) influenced by prey density and hunger. Mar Biol 122:205-212

Munk P (1997) Prey size spectra and prey availability of larval and small juvenile cod. J Fish Biol 51(Suppl):340-351

Munk P, Larsson PO, Danielssen DS, Moksness E (1999) Vari-

Editorial responsibility: Howard Browman (Associate Editorin-Chief), Storebø, Norway ability in frontal zone formation and distribution of gadoid fish larvae at the shelf break in the northeastern North Sea. Mar Ecol Prog Ser 177:221-233

Nissling A (2004) Effects of temperature on egg and larval survival of cod (Gadus morhua) and sprat (Sprattus sprattus) in the Baltic Sea-implications for stock development. Hydrobiologia 514:115-123

Parmanne R, Rechlin O, Sjoestrand B (1994) Status and future of herring and sprat stocks in the Baltic Sea. Dana 10: 29-59

Pearre S Jr (1982) Estimating prey preference by predators: uses of various indices, and a proposal of another based on $\chi^{2}$. Can J Fish Aquat Sci 39:914-923

Pearre S Jr (1986) Ratio-based trophic niche breadths of fish, the Sheldon spectrum, and size-efficiency hypothesis. Mar Ecol Prog Ser 27:299-314

Pelegrí SP, Dolan J, Rassoulzadegan F (1999) Use of high temperature catalytic oxidation (HTCO) to measure carbon content of microorganisms. Aquat Microb Ecol 16: $273-280$

Pepin P (2004) Early life history studies of prey-predator interactions: quantifying the stochastic individual response to environmental variability. Can J Fish Aquat Sci 61: 659-671

Pepin P, Penney RW (1997) Patterns of prey size and taxonomic composition in larval fish: Are there general sizedependent models? J Fish Biol 51:84-100

Reiss C, McLaren I, Avendano P, Taggart C (2005) Feeding ecology of silver hake larvae on the Western Bank, Scotian Shelf, and comparison with Atlantic cod. J Fish Biol 66: $703-720$

Scharf FS, Juanes F, Rountree RA (2000) Predator size-prey size relationships of marine fish predators: interspecific variation and effects of ontogeny and body size on trophicniche breadth. Mar Ecol Prog Ser 208:229-248

Sokal RR, Rohlf FJ (1995) Biometry: the principles and practice of statistics in biological research. WH Freeman, New York

Stoecker DK, Govoni JJ (1984) Food selection by young larval gulf menhaden (Brevoortia patronus). Mar Biol 80: 299-306

Viitasalo M, Flinkman J, Viherluoto M (2001) Zooplanktivory in the Baltic Sea: a comparison of prey selectivity by Clupea harengus and Mysis mixta, with reference to prey escape reactions. Mar Ecol Prog Ser 216:191-200

Voss R (2002) Recruitment processes in the larval phase: the influence of varying transport on cod and sprat larval survival. $\mathrm{PhD}$ thesis, University of Kiel

Voss R, Koester FW, Dickmann M (2003) Comparing the feeding habits of co-occurring sprat (Sprattus sprattus) and cod (Gadus morhua) larvae in the Bornholm Basin, Baltic Sea. Fish Res 63:97-111

Voss R, Clemmesen C, Baumann H, Hinrichsen HH (2006) Baltic sprat larvae: coupling food availability, larval condition and survival. Mar Ecol Prog Ser 308:243-254

Submitted: November 17, 2005; Accepted: December 6, 2006 Proofs received from author(s): July 3, 2007 